\title{
STUDYING TIMES OF STUDENTS IN ASYNCHRONOUS FORMS OF DISTANT EDUCATION: FACTS AND MYTHS
}

\author{
Anna Ślósarz \\ Pedagogical University of Krakow \\ Podchorążych 2, 30-084 Kraków, Poland \\ anna.slosarz@up.krakow.pl, ORCID 0000-0001-5524-3227
}

\begin{abstract}
The aim of the study was to identify studying times preferred by students participating in asynchronous forms of distant education. It was carried out using the instrumental, collective case study method, which allowed comparing cases and examining them in a context.

At the beginning of the academic year, familiarising themselves with e-learning, students participated in online classes. Soon, they did not require further assistance. Initially, the majority of students did the tests shortly after the classes, but after a few sessions they did them before the classes. Students, for whom e-learning was new, usually took one test before the classes while experienced ones did several in one go. Students preferred to study in the evenings and at night. This means that distance education should incorporate the asynchronous delivery mode. University authorities need to regulate distance education which, in accordance with the Act and the ordinance of the Minister of Education, in addition to the dominant at Polish universities synchronous delivery mode, should allow also for asynchronous forms of distant education delivery mode. It is a myth that asynchronous mode of study weakens the bond between student, and between students and their lecturer. This common misconception myth disadvantages Polish universities, because corporations as well as the world highest-ranked universities offer MOOC and on-demand courses.
\end{abstract}

Keywords: students, study plan, instructions, test, post, evening, procrastination.

\section{INTRODUCTION}

Polish legislation on labour law in higher education allows delivering distance education courses in synchronous and asynchronous mode (Higher Education Labour Law, Art. 67, p. 4).

During the COVID-19 pandemic, the authorities of almost all Polish universities decided that classes were to be conducted in a synchronous mode using a videocon- 
ference system, such as MS Teams. Lectures and tutorials were held at specified times according to the time table which had been developed for on-campus teaching. Following the schedule for distant education made it easier for decision-makers to control its delivery, for example the headmaster logged in at specified times to check whether the classes had started on time.

For both students and teachers synchronous distance education turned out to be psychologically and physically exhausting (Długosz, 2020a: 21; Długosz, 2020b: 4, 26, 42; Gruszczyńska, 2020: 27). The lecturers shared texts, books and other documents in pdf format, however disregarding students' time constraints. The students were expected to read the materials over the semester, and also participate in lectures, tutorials, workshops and on-line seminars.

On the other hand, Peter C. Herman aptly observed that "The major advantage of online learning is asynchronicity, or, «anytime, anywhere learning»." (2020). Asynchronicity, technology-mediated interaction and engagement are fundamentals of e-learning (Vrasidas, Zembylas, 26; Kędzierska, Ślósarz, Ratusiński, Skrzypek, 2014; Stowarzyszenie E-learningu Akademickiego, 2008). It requires the lecturer's immediate feedback (Alvarez, 2012) and personal reflections, collaboration, dialogic interactions, exchange information and ideas (Sparnon, 2004). They are more challenging to organise than a videoconference. Preparing not only study materials but also forms of self-assessment, tests, marking criteria and designing a course prior to its commencement requires competence and time investment on the part of the lecturer. On the other hand, asynchronous studies do not require any preparation of a detailed plan of studies or application of complicated technology (Anderson, 1997-1998). Such an approach is often used in medical field (White et al., 2021) as it gives students opportunity to study $24 / 7$.

Therefore, it is worth to investigate at what time students are most inclined to study when they are given freedom of choice. The study presented in this paper is an attempt to answer the above question. It was conducted to examine to what extent synchronous distance education offered by a number of Polish universities is practical, whereas foreign universities for some time have been successfully offering asynchronous courses (Picciano, 2002; Blignaut \& Trollip, 2003; Cheung \& Hew, 2004; Dennen, 2005; Peterson et al., 2018), corporations offer more and more studies on-demand (SHRM, 2021), and the world's highest ranked universities offer MOOC courses allowing the students to work at their own pace (Coursera, EdX).

\section{AIM, HYPOTHESIS AND METHODS}

The aim of this study was to identify the time students typically undertook e-learning activities. As part of the netographic study, the daily practices and unique behaviours of students in specific groups were analysed in order to determine the scope of a wider phenomenon i.e. the rationale and effectiveness of on-line courses delivered in asynchronous mode.

The following hypothesis was formulated: the majority of students undertakes e-learning activities as per schedule. 
The instrumental, collective case study method was used (Stake, 2009; Creswell, 2012), which allowed placing the cases within a larger context, understanding them better, and making comparisons, which provided a better insight into an issue (Cresswell, 2012, 465). The inductive and deductive stages of qualitative methods were used for data analysis (Patton, 2002, 18; Stake, 2011, 20).

Objective data was collected in the form of digital records of times at which students submitted individual tests. Data was entered into an Excel spreadsheet. Then, the frequency of specific values e.g. 9.00 a.m., 5.00 p.m. was calculated with the help of an internal search engine. The obtained results were presented as charts in order to establish trends, variabilities as well as the similarities and differences. Qualitative analysis included characteristics of the group and compared it with other groups. After analysing the data, assertions were formulated and grouped into categories for and against asynchronous education. Based on careful data analysis, all assertions supported by enough evidence were adopted. The results were also compared with those published by other researchers.

\section{RESEARCH MATERIAL}

The research material consisted of automatically registered times at which students enrolled in four different off-campus courses offered at the Institute of Polish Philology at Pedagogical University in Cracow in the summer semester of academic year 2019/2020 and 2020/2021 submitted their assignments. Classes were delivered on the MOODLE platform in asynchronous and synchronous modes, i.e. all or almost all study materials were made available to students before the first class so they were able to study at the time convenient to them. Additionally, students were able to meet the lecturer during scheduled online sessions. They were, therefore, able to study at their own pace and many completed particular modules or entire course well before the due date. The university courses were run in a synchronous mode, and online sessions were delivered according to the timetable set for on-campus education.

After each class, students were required to do an assignment. Three attempts were allowed. Students took second or third attempt if they failed the test or in order to get a higher score. Assignments had no weighting for the final mark. These were mandatory pass/fail tests. However, in the case of the first two courses the high mean test score improved the final mark.

The analysed modules were selected in such a way as to provide as much information as possible: two courses, courses delivered bachelor's and master's degrees level, modules from the 2019/2020 and 2020/2021 academic years, lectures, tutorials and workshops as well as on-campus and off-campus modes of study.

The lecturer had sessions with the students at set times. In academic year 2019/2020, the lecturer communicated with the students by exchanging posts on the forum, and in 2020/2021via BigBlueButton. At the beginning of each session, the lecturer discussed the main topics, provided information on how many students had already completed modules, and provided full names of students who scored $100 \%$ in the tests. Over time, the number of participants in these meetings decreased because they either did not need to continue mentorship, or had already completed the module or 
the entire course. Nonetheless, the synchronous contact with the lecturer was available over the entire course, according to the timetable. However, not many students participated in real-time meetings. That could have been due to the difficulties associated with the observance of real time meetings. Therefore, students usually posted their queries and requests to the lecturer outside of scheduled meetings.

Table 1. Analysed courses

\begin{tabular}{|c|c|c|c|}
\hline Course & Class & Level, Semester & $\begin{array}{c}\text { No. of } \\
\text { participants }\end{array}$ \\
\hline \multicolumn{4}{|c|}{ Course: Cultural Studies and Media Knowledge } \\
\hline $\begin{array}{l}\text { Contemporary Media } \\
\text { Systems }\end{array}$ & Lectures, tutorials & $\begin{array}{l}\text { Bachelor's first semester, } \\
2019 / 2020\end{array}$ & 50 \\
\hline $\begin{array}{l}\text { Basics of Social } \\
\text { Communication }\end{array}$ & Lectures, tutorials & $\begin{array}{l}\text { Bachelor's second } \\
\text { semester, 2020/2021 }\end{array}$ & 13 \\
\hline $\begin{array}{l}\text { Neurocognitive Analysis } \\
\text { of Cultural Texts }\end{array}$ & Tutorials & $\begin{array}{l}\text { Master's, first semester, } \\
\text { 2019/2020 }\end{array}$ & 20 \\
\hline \multicolumn{4}{|c|}{ Course: Polish Philology } \\
\hline $\begin{array}{l}\text { Multimedia in Social } \\
\text { Communication }\end{array}$ & Workshops & $\begin{array}{l}\text { Bachelor's first semester, } \\
2020 / 2021\end{array}$ & 14 \\
\hline Total & & & 97 \\
\hline
\end{tabular}

Source: Own work.

\section{LIMITATIONS}

The author of this study attempted to establish preferred studying times of students of a given university. The results cannot be generalised due to a small research sample, preparation and delivery of classes by one lecturer only, as well as only two academic terms and one Institute of the university. Moreover, attending tests prior to class could have been influenced by the student's hope to be praised by the lecturer by having their name revealed to other students had they achieved $100 \%$. The way students studied might have also been influenced by the social context - the pandemic caused uncertainty as to the possibility of continuing studies. Thus, students might have been more inclined to study systematically. The case study presents behaviours of individual students only. Nonetheless, it allows for applying identified behaviours to a broader population i.e. all studied groups and the entire population of students.

\section{RESULTS}

\subsection{Step One: Need for Mentorship}

Cultural Studies and Media Knowledge students who were enrolled in the unit Contemporary media systems in the second semester, had not had any experience with the MOODLE platform. After the onset of the pandemic, most of the classes were 
delivered via the newly purpose-adapted videoconferencing services such as Microsoft Teams, ZOOM, or Google Meet.

However, students were prepared for classes being delivered on the MOODLE platform, because at the beginning of the second semester they had been provided with study materials and assignments the same as for the lectures delivered on-campus. The student's main task was to post on the forum a Power Point presentation based on the readings which had already been presented to the students on campus. Students needed thorough instructions at the beginning of their e-learning experience, so they could master their platform navigation skills. Instructions were provided to the students face-to-face, and then via group and individual posts on the MOODLE platform.

Before the first online lecture, and the third in general, the lecturer posted detailed information on how distance learning would be delivered. The lecturer provided similar information prior to and during the following online sessions. Thanks to this, sessions ran smoothly. There were no organisational or technical issues. A hundred percent of students participated in the online lectures and tutorials. Such high attendance is uncommon in the case of on-campus classes. The lecturer provided students with further instructions during the first few online sessions. As scheduled, the lecture was delivered 11.30 a.m. - 1.00 p.m. on Thursdays, and tutorials 9.15 p.m. 1.45 p.m. - on Mondays for group I, and on Fridays for group II.

Figure 1 below shows that students attending group sessions, rarely completed their assignments during sessions. Students studied hardest between 5.00 p.m. and 7.00 p.m. $36 \%$ of students studied after 8.00 p.m., at the time when on-campus sessions are hardly ever delivered. Therefore, it can be said that every third student preferred to study in the evening rather than during the day (including during scheduled sessions).

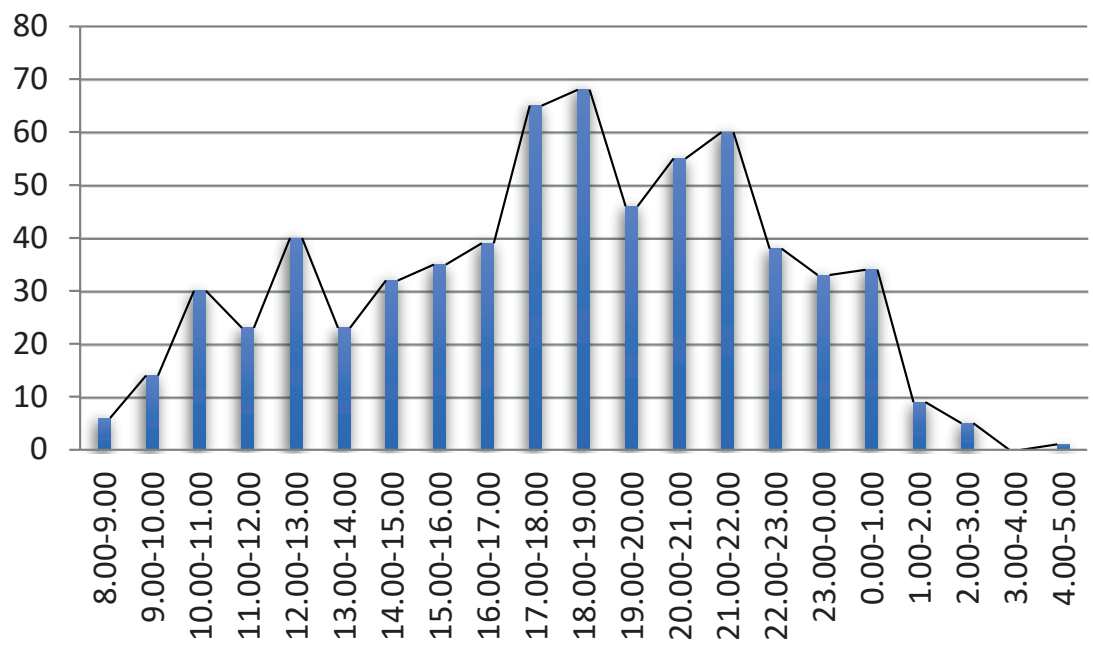

F ig u r e 1. Studying times of first year BA students of Cultural Studies and Media Knowledge

Source: Own work. 
It follows that asynchronous mode was useful. Classes for the second group had been scheduled to be delivered in May. Nonetheless, students logged in at the same time as the first group students and were completing modules ahead of the schedule. They studied systematically, so they were ready to take an exam before the scheduled exam session. Almost $100 \%$ of students completed their assignments and posted their presentations at the forum before the deadline. Preparation of a presentation was a challenging task. Therefore, it was decided that a student who did not prepare a presentation on time would be required to prepare an additional one. That might be one of the reasons why students posted their presentations ahead of the deadline in order to avoid the risk of e.g. difficulties with internet connection.

Figure 2 shows that almost all students completed the tests and assignments prior to the classes, rarely during and hardly ever after them.

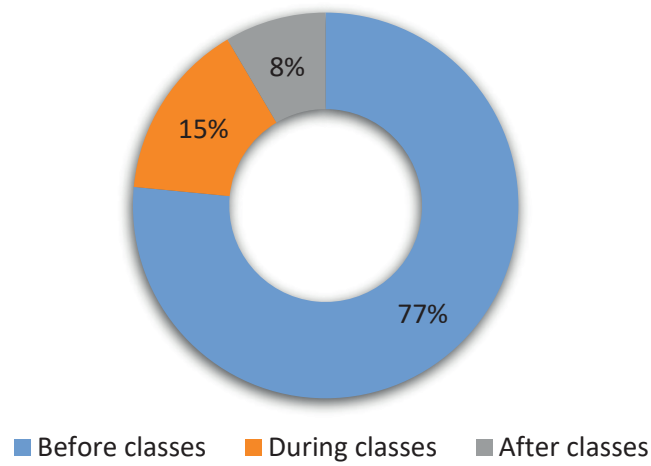

\section{Figure 2. Studying times of first year BA students of Cultural Studies and Media Knowledge}

Source: Own work.

It was found that the students in the group were committed and ambitious. Two lectures delivered on campus gave students and the lecturer the opportunity to establish a good rapport with each other, which in distant education is of significant importance. This hypothesis was confirmed by excellent exam results - the average was close to high distinction. 7 students (14\%) dropped out, which is quite common in the first year.

The following year, students who studied in a similar system, did not achieve such a high exam mean result, one student failed the exam and twenty-nine students (31\%) dropped out. It seems that reasons for the lower marks could be that it was impossible to meet on the campus that year. Additionally, the pandemic weakened the collegial bonds necessary for preparing group presentations. It also made it difficult for students to get to know the lecturer, and for the lecturer - to understand the needs of the students. However, earlier research suggested that asynchronous learning actually fosters a very high degree of interaction among students and instructors (Wilson \& Weiser, 2001: 365). A number of researchers share this opinion (Mayadas, 1997; Miller \& Webster, 1997; Koehler et al. 2020). Therefore, it can be said that blended learning, i.e. in this case the first two classes delivered face-to-face followed by 
distant education in 2019/2020 because of the pandemic - triggered dedication in students and provided them with the opportunity to study asynchronously, which turned out to be highly effective.

\subsection{Part-Time Students: Time Saving}

Second-year BA students of Cultural Studies and Media Knowledge completed Basics of Social Communication unit delivered entirely in distant education mode. They had been familiar with e-learning, because in the first year they completed two units delivered in this way: Contemporary Media Systems and Information and Communication Technologies for a Culture Expert. The off campus mode of delivery meant that students frequently studied during scheduled hours due to their work commitments. The spike at 1.00 p.m. in Figure 3 was due to ten lectures and tutorials conducted between 1.00 p.m. and 2.00 p.m.

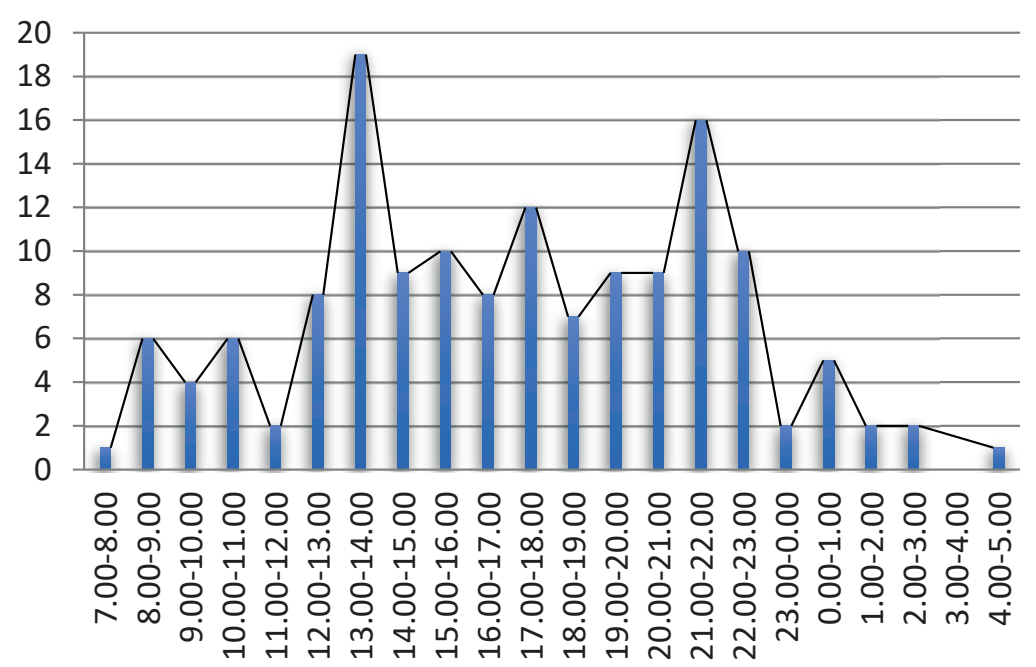

Figure 3. Studying times of second year BA students of Cultural Studies and Media Knowledge in distant education mode

Source: Own work.

The high position of 9.00 p.m. and the neighbouring hours in Figure 3 also deserves attention. Distant education students completed $32 \%$ of their units after 8.00 p.m., due to their other commitments.

Students did not work systematically. They frequently completed assignments after the sessions, often after the next scheduled class. Inexperienced students procrastinated (Sanecka, 2019), which accounted for their falling behind. Nonetheless, they were able to make up on time. Figure 4 presents the scale of this phenomenon. It suggests that although students frequently completed their assignments before the class, the procrastination rate reached $37 \%$, and it was the highest for all four studied groups. 


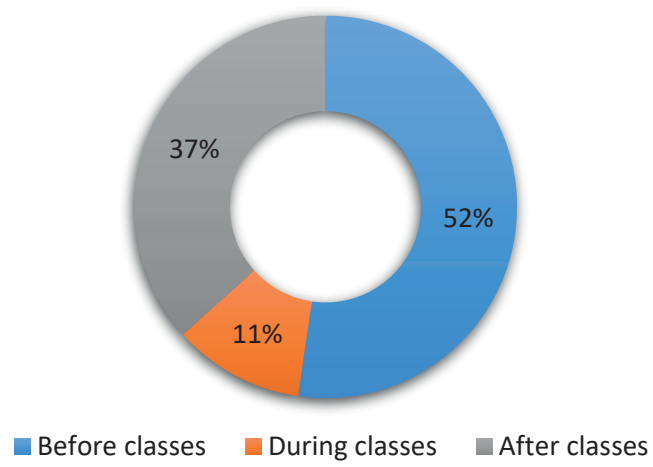

F ig u r e 4. Test taking times of second year BA students of Cultural Studies and Media Knowledge in distant education mode

S ou r ce: Own work.

Students did not need any detailed instruction or arrangements at the beginning of the course. The majority participated in the first two sessions. Some students completed their assignments at the scheduled times, others - at a later date. Starting from the third session, most students completed their assignments prior to the scheduled sessions; tests were also less often attempted during session times. This is illustrated in Figure 5. The unequal numbers of students attempting tests during sessions resulted from the fact that some students attempted their assignments twice or three times in order to increase their score and final grade. Additionally, as one absence was allowed, some students completed tests at a later date, which accounts for the spike in figures.

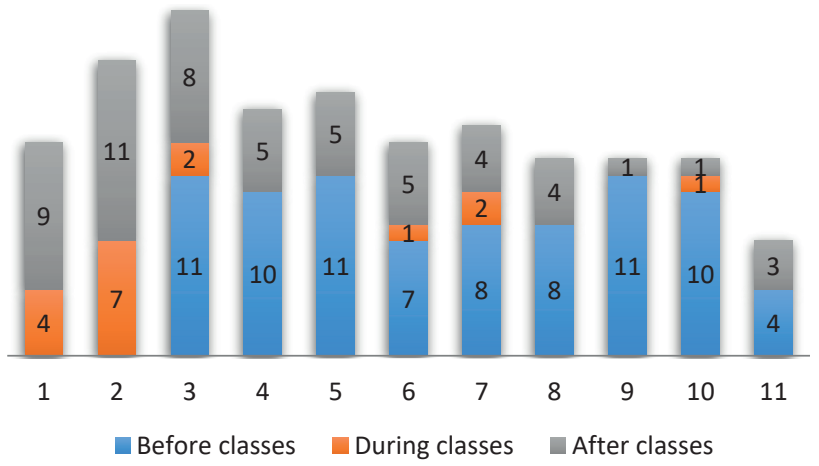

F i g u r e 5. Assignment completion times of second year BA students of Cultural Studies and Media Knowledge

S ou r e: Own work.

Despite being well behind with their studies, experienced students were able to make up by participating in unsupervised distance learning (Fernández-Aleman et al., 2016) and completing several modules at one sitting. All students - except for the one who dropped out - completed unit on time. All students passed the exam 
before the formal examination period. They had established a good relationship with the course coordinator and were familiar with the course program (Schroeder et al., 2016). Therefore, they were able to use e-resources proficiently. Nonetheless, work and other commitments posed a significant challenge for some of them.

\subsection{Students Unfamiliar with MOODLE}

The majority of second-year students of Polish Philology studied during the scheduled hours when completing the Multimedia in Social Communication unit. Sessions were held on Thursdays from: 3.15 p.m. -4.45 p.m. Figure 6 shows that most students studied during the first hour of classes; they had also studied intensely prior to them. Some students participated in a group session with the intention of completing their assignments at a later date. Therefore, there was lower attendance in the second hour of the session.

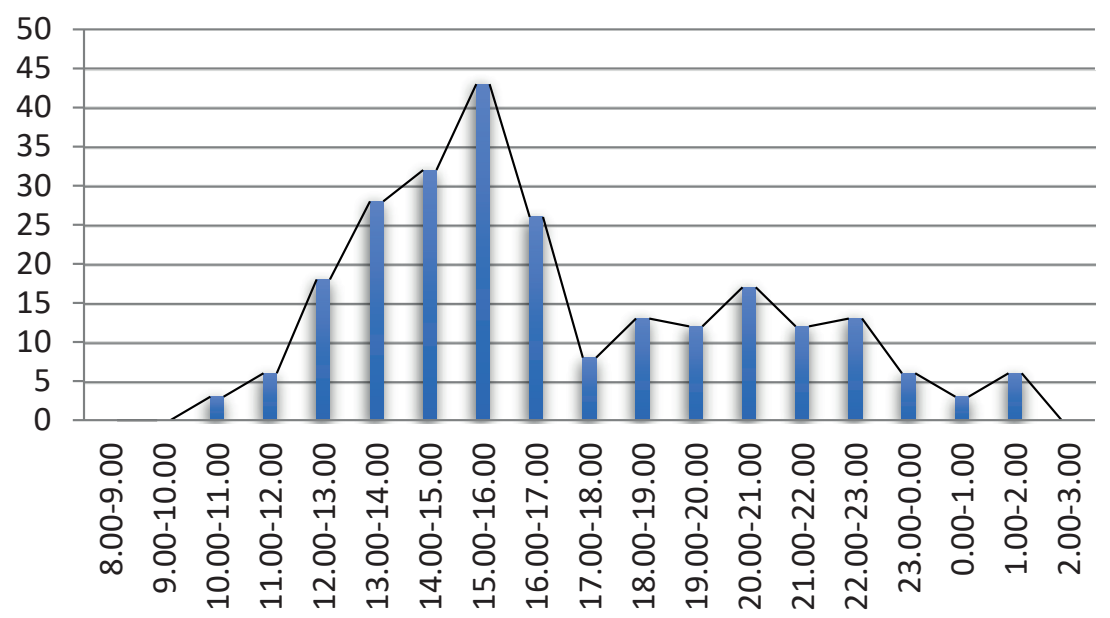

F i g u r e 6. Assignment completion times of second year BA students of Polish Philology

Source: Own work.

Second-year students had previously completed a few sessions delivered on the MOODLE platform so they were familiar with it. However, these sessions mainly involved accessing study resources files (called Resources for students), i.e. the repositories. Therefore, students from this group were unfamiliar with e-learning. The student-representative of the group stated that that was their first Moodle unit to complete.

They studied systematically, hardly ever anyone fell behind. They aimed at completing the tests before the scheduled date. $23 \%$ of the assignments were completed after 8.00 p.m. Over time, fewer and fewer students studied during session times, preferring to study independently. The evening and night study times were preferred for posting presentations and commenting on their colleagues' posts. $36 \%$ of these were posted after 8.00 p.m. Preparing the posts required more attention and focus than ten-minute tests. Therefore, the students preferred to edit them when they had no 
time limits. It can be said that for these students their first distant education course became an opportunity for developing their independent-learning strategy. Figure 7 shows that $77 \%$ students worked before classes.

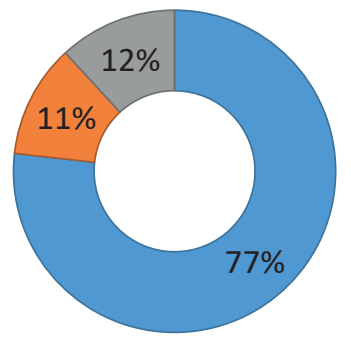

Before classes $\square$ During classes $\square$ After classes

\section{F ig u r e 7. Test taking times of second year BA students of Polish Philology}

Source: Own work.

This was the most committed group. The students diligently followed instructions. They studied systematically, on average completing one assignment, i.e. one module, a week. None of the students fell behind with their studies and all of them completed the unit on time.

\subsection{Experienced Students: Independent Studying}

The Neurocognitive Study of Cultural Texts unit delivered in distance education mode was completed in the second semester of the 2019/2020 academic year by the first-year MA students of Cultural Studies and Media Knowledge. There were 20 students in the group. All students completed e-learning units during their bachelor degree course. Therefore, they were familiar with this mode of education and, indeed, utilised their skills freely and independently.

Most of the sessions were held between 3.30 p.m. and 5.00 p.m. However, as Figure 8 shows, students hardly ever studied at these times. They preferred to study in the evening hours, especially after 6 p.m. $36 \%$ of the quizzes were completed after 8 p.m. that is the highest percentage for all surveyed groups. This finding suggests that there is a high demand for asynchronous mode of learning, especially in the case of students with advanced skills in e-learning. It can be said, therefore, that every third student from this group studied in the evening, independently of the timetable.

The joint meetings were rarely logged in because the instructions were clear, so no additional clues were needed.

Experienced students were comfortable in planning their study times independently. Therefore, they did not need to participate in sessions delivered in real time. They studied at their own pace, often completing several assignments at one sitting, before or after sessions. Hence, a relatively high percentage of the students who completed their assignments after the session, as illustrated in Figure 9. Only 1\% of the students completed tests according to the timetable. Only a few joined online sessions because instructions were clear, and they did not require additional information. 


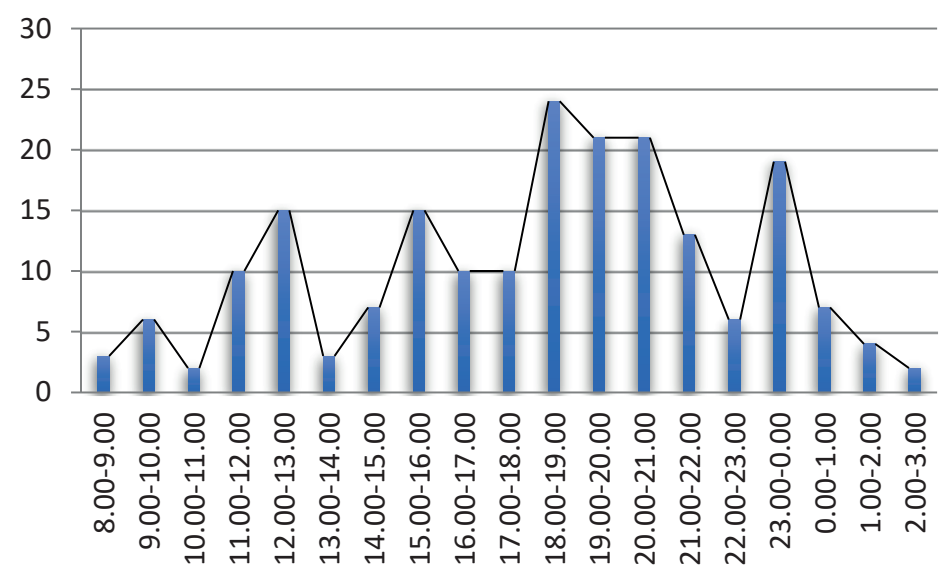

F i g u r e 8. Studying times of first year MA students of Cultural Studies and Media Knowledge

S o u r ce: Own work.

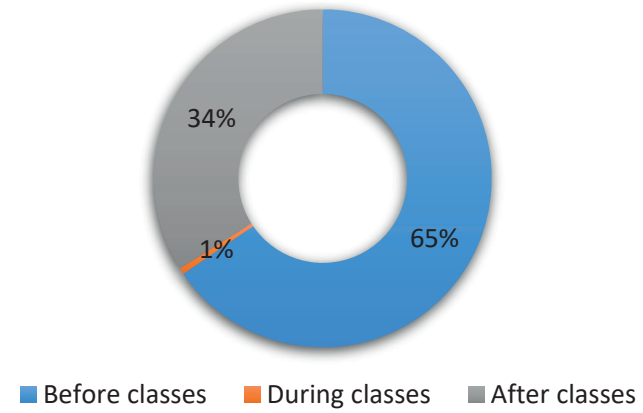

F i g u r e 9. Study times of first year MA students of Cultural Studies and Media Knowledge

S ource: Own work.

On the discussion forum, the students presented their reflections based on selected readings and their own experiences. Their posts were a mandatory requirement for successful completion of the unit. Alike their inexperienced colleagues enrolled in the Multimedia in Social Communication unit who completed 23\% of their assignments after 8 p.m., they also preferred to study in the evening. Seven out of twenty comments were posted after 8 p.m., which amounts to $35 \%$. This means that both extremely inexperienced and highly experienced students preferred to work asynchronously while completing the distant education course.

Figure 10 illustrates study patterns of experienced e-learning students. It shows that students preferred asynchronous contact with the lecturer, and that they required instructions only at the beginning of the course. Over time, they completed all assignments prior to sessions.

Thus, master's degree students were able to successfully organise their learning by taking advantage of the asynchronous study mode. 


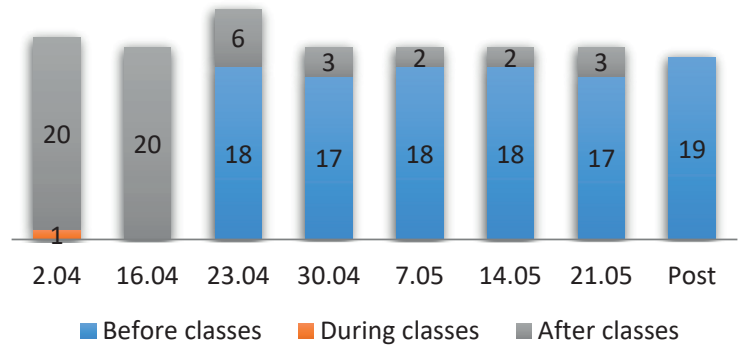

\section{F ig u r e 10. Assignment completion of first year MA students of Cultural Studies and Media Knowledge}

S o u r ce: Own work.

\section{CONCLUSION}

The hypothesis that the majority of students undertakes e-learning activities according to the timetable has not been confirmed. Thus, it can be argued that enforcing synchronous mode of distant education by universities can be justified neither methodologically nor organisationally. As students gain experience in completing modules delivered on the MOODLE platform in asynchronous mode, they need less and less synchronous instructions. Moreover, experienced students do not need them at all. Students completed assignments asynchronously and in large blocks. They studied at times convenient to them and at their own pace.

The majority of students completed modules and entire units before the due date. Many students also studied after scheduled sessions times or did not participate in synchronous interactions at all. It seems that students were avoiding synchronous interactions preferring to study independently. They seemed to be least satisfied when required to follow the study regime imposed by the timetable.

The surveyed students needed one or two meetings with the course coordinator at the beginning of the course to familiarise themselves with the unit's rules and expectations. Therefore, for the future, it would seem reasonable to deliver the first two classes on campus, and the rest asynchronously. Those sessions should be audiovisual, and delivered in real-time so that the students could get to know the lecturer and the lecturer - the students. It is recommended that universities install the BigBlueButton application along with the commonly used Microsoft Teams. It is a myth that BigBlueButton slows down the system. It is successfully used on the MOODLE platform, for example by the University of Wrocław and by the Pedagogical University in Krakow from 2021/2022 academic year.

The argument that distant education negatively influences the students-lecturer and student-student relationship is a risky myth resulting from an inappropriate use of videoconferencing and negative attitudes the majority of university staff have towards distant education. That is the case because organising distant education requires huge time investment while academics seem to prefer to dedicate their time to research and publishing. 
Study times of students of enrolled in asynchronously delivered courses require extensive research. The aim of research is to suggest improvements to practice (Cresswell, 2012: 4). In the $21^{\text {st }}$ century, the coherent vision of quality education requires inclusion of distant education delivered in asynchronous mode.

\section{ACKNOWLEDGEMENTS}

The work presented in this paper has been supported by the funds obtained for statutory research within Social Communication in the $20^{\text {th }}$ and $21^{\text {st }}$ century: linguistic, socio-cultural, media, political and legal aspects project (Research Project No. 8).

\section{REFERENCES}

A lvarez, I., Espana, A., \& Gu a s ch, T. (2012). The value of feedback in improving collaborative writing assignments in an online learning environment. Studies in Higher Education, 37(4), 387-400. Print ISSN 0307-5079, online ISSN 1470-174X, https://doi.org /10.1080/03075079.2010.510182.

Anderson, M.D. (1997-1998). Critical Elements of An Internet Based Asynchronous DistanceEducation Course. Journal of Educational Technology Systems, 26(4), 383-388. Print ISSN 0047-2395, online ISSN 1541-3810, https://doi.org/10.2190/BMBA-WN45-PL 5F-XDBN.

Blig n a ut, A.S. \& Troll ip, S.R. (2003). Measuring Faculty Participation in Asynchronous Discussion Forums. Journal of Education for Business, 78(6), 347-353. Print ISSN 08832323, online ISSN 1940-3356, https://doi.org/10.1080/08832320309598625.

Che ung, W.S. \& Hew, K.F. (2004). Evaluating the Extent of Ill-Structured Problem Solving Process among Pre-Service Teachers in an Asynchronous Online Discussion and Reflection Log Learning Environment. Journal of Educational Computing Research, 30(3), 197-227. Print ISSN 0735-6331, online ISSN 15414140, https://doi.org/10.2190/9JTN-10 T3-WTXH-P6HN.

„Coursera” (2021). Achieve your goals with Coursera. Retrieved from https://www.coursera. org (accessed 23.08.2021).

Cress well, J.W. (2012). Case Studies. In idem. Educational Research. Planning, Conducting, and Evaluating Quantitative and Qualitative Research (4 ${ }^{\text {th }}$ ed.). Boston: Pearson, pp. 465-466. ISBN-13: 978-0-13-136739-5, ISBN-10: 0-13-136739-0.

D e n n en, V.P. (2005). From message posting to learning dialogues; Factors affecting learner participation in asynchronous discussion. Distance Education, 26(1), 127-148. Print ISSN 1475-1098, online ISSN 0158-7919, https://doi.org/10.1080/01587910500081376.

Dłu go sz, P. (2020a). Raport z badań: „Krakowscystudenci w sytuacji zagrożenia pandemmia koronawirusa” [Research report: „Cracow students in the event of a coronavirus epidemic threat"]. Kraków: Instytut Filozofii i Socjologii Uniwersytetu Pedagogicznego im. Komisji Edukacji Narodowej w Krakowie [Krakow: Institute of Philosophy and Sociology at the Pedagogical University of National Education Commission in Krakow]. ISBN 978-83-8084-546-6. Retrieved from https://rep.up.krakow.pl/xmlui/handle/11716/10085 (accessed 10 July 2021). 
Długosz, P. (2020b). Raport z II etapu badań studentów UP. Opinia na temat zdalnego nauczania $i$ samopoczucia psychicznego [Report from the $2^{\text {nd }}$ stage of UP students' research. Opinion on remote teaching and mental well-being]. Kraków: Instytut Filozofii i Socjologii Uniwersytetu Pedagogicznego im. Komisji Edukacji Narodowej w Krakowie [Krakow: Institute of Philosophy and Sociology at the Pedagogical University of National Education Commission in Krakow]. Retrieved from https://rep.up.krakow.pl/xmlui/ handle/11716/7488 (accessed 23.08.2021).

"EdX” (2021). Explore top courses. Retrieved from https://www.edx.org (accessed 23.08.2021).

Fer nánd ez-A léma n, J.L., Ló pez-González, L., González-S equeros, O., Jayne, Ch., López-Jiménez, J., Manuel Carrillo-de-Gea, J., \& Toval, A. (2016). An Empirical Study of Neural Network-Based Audience Response Technology in a Human Anatomy Course for Pharmacy Students. Journal of Medical Systems, 40(85). Print ISSN 0148-5598, online ISSN 1573-689X, https://doi.org/10.1007/s10916-016-04 40-6. Retrieved from https://link.springer.com/article/10.1007/s10916-016-0440-6 (accessed 23.08.2021). https://doi.org/10.1007/s10916-016-0440-6.

Gruszczyńska, E. (2020) Kształcenie wyższe na odległość: Jednak poszukiwanie nowych odpowiedzi na stare pytania. In J. Lubacz (Ed.). Nauczanie po pandemii. Nowe pytania czy nowe odpowiedzi na stare pytania? (pp. 25-32), Warszawa: Instytut Problemów Współczesnej Cywilizacji im. Marka Dietricha. ISBN 978-83-89871-43-5. Retrieved from http://www.ipwc.pw.edu.pl/pliki/Nauczanie-po-pandemii-2020.pdf (accessed 23.08.2021).

Her m a n, P.C. (2020). Online Learning Is Not the Future, 10 June. Retrieved from https:// www.insidehighered.com/digital-learning/views/2020/06/10/online-learning-not-future-higher-education-opinion (accessed 23.08.2021).

Kę d zier ska, B., Ślós a r z, A., Rat u s iński, T., \& Skrzy pek, W. (2014). Poradnik dla osób przygotowujących zajęcia / kursy w formie zdalnej [Guide for persons preparing classes / courses in a remote form]. Retrieved from https://moodlel.up.krakow.pl (accessed 23.08.2021).

Ko ehler, A.A., Cheng, Z., Fiock, H., Jan a kir a ma n, S., \& Wa ng, H. (2020). Asynchronous Online Discussions During Case-Based Learning: A Problem-Solving Process, Online Learning, 24(4), 64-92. https://doi.org/10.24059/olj.v24i4.2332. Retrieved from https://olj.onlinelearningconsortium.org/index.php/olj/article/view/2332/996 (accessed 23.08.2021).

Ma y a d a s, A.F. (1997). Online networks build time savings into employee education, $H R$ Magazine, 42(10), 31-35. ISSN 1047-4398.

Miller, W.W. \& Webster, J.K. (1997). A comparison of interaction needs and performance of distance learners in synchronous and asynchronous classes. Paper presented at the AVAC, Las Vegas, December 1997.

Pat to n, M. (2015). Qualitative research \& evaluation methods. London: Sage. ISBN 978-14129-7212-3.

Peterson, A.T., Beymer P.N., \& Putnam R.T. (2018). Synchronous and Asynchronous Discussions: Effects on Cooperation, Belonging, and Affect, Online Learning22(4), 7-25. ISSN 2472 -5749. Retrieved from https://eric.ed.gov/?id=EJ1202382 (accessed 23.08.2021), https:// doi.org/10.24059/olj.v22i4.1517. 
Piccia n o, A.G. (2002). Beyond student perceptions: Issues of interaction, presence, and performance in an online course. Journal of Asynchronous learning networks, 6(1), 2140. Print ISSN 1939-5256, online ISSN 092-8235, https://doi.org/10.24059/olj.v6i1.1870.

Prawo pracy w szkolnictwie wyższym i nauce. Ustawa $z$ dnia 20 lipca 2018 r., Dz.U. 2018 poz. 1668. Retrieved from https:/isap.sejm.gov.pl/isap.nsf/download.xsp/WDU20180001668/ U/D20181668Lj.pdf (accessed 23.08.2021).

S a n e cka, E. (2019). Procrastination in Blended Learning. The Role of General Self-efficacy, and Active and Passive Procrastination. International Journal of Research in E-learning, 5(2), 49-65. Retrieved from https://journals.us.edu.pl/index.php/IJREL/article/view/ 8430 (accessed 12.07.2021). Print ISSN 2451-2583, online ISSN 2543-6155, https:/doi. org/10.31261/IJREL.2019.5.2.04.

Schroeder, S., B a ker, M., Terras, K., Mahar, P., \& Chi a s son, K. (2016). Students' Desired and Experienced Levels of Connectivity to an Asynchronous, Online, Distance Degree Program. Journal of Asynchronous Learning Networks, 20(3), 244-263. ISSN 1939-5256. Retrieved from https://www.learntechlib.org/p/193378 (accessed 23.08.2021).

„SHRM. Better workplaces better world” (2021). SHRM e-learning. Retrieved from https:// www.shrm.org/LearningAndCareer/learning/Pages/SHRM-eLearning.aspx (accessed 23.08.2021).

S p a r n o n, D. (2004). Online at Midnight: MLIS opportunities, Knowledge Quest, 3(1), 38-39.

S t a ke, R.E. (2009). Jakościowe studium przypadku, transl. M. S a ł ko w s k a. In N.K. D e n z i n, \& Y.S. Li n coln (Eds.). Metody badań jakościowych, Vol. 1, Warszawa: Wydawnictwo Naukowe PWN. ISBN 978-83-01-15880-4.

St a ke, R.E. (2011). Qualitative research: Studying how things work. New York, NY: The Guilford Press. ISBN-13: 978-1-606235454, ISBN-10: 1606235451.

Stowarzyszenie E-learningu Akademickiego. (2008). Kryteria oceny kursu internetowego [Criteria for assessing the online course]. Retrieved from https://sea.edu.pl/kryteria (accessed 23.08.2021).

Vrasid as, C. \& Ze mbylas, M. (2003). The nature of technology-mediated interaction in globalized distance education. International Journal of Training and Development, 7(4), 1-16. Online ISSN 1468-2419.

White, M.J., Birkness, J.E., S a li mia n, K.J., Me is s, A.I., B u t cher, M., D avis, K., Wa re, A.D., Z a rella, M.D., L e ck sell, K., R o o per, L.M., Ci m in o-M a the w s, A., Canden Bus sche, J.V., Ha lu sh ka, M.K., \& Thompson, E.D. (2021). Continuing Undergraduate Pathology Medical Education in the Coronavirus Disease 2019 (COVID-19) Global Pandemic, 1 July. Archives of Pathology \& Laboratory Medicine, 145(7), 814820. Retrieved from https://pubmed.ncbi.nlm.nih.gov/33740819 (accessed 23.08.2021). https://doi.org/10.5858/arpa.2020-0652-SA, online ISSN 1543-2165.

Wils on, R.L. \& We is er, M. (2001). Adoption of Asynchronous Learning Tools by Traditional Full-Time Students: A Pilot Study, Information Technology and Management, 2, 363-375. https://doi.org/10.1023/A:1011446516889. Retrieved from https://link.springer. com/article/10.1023/A:1011446516889\#citeas (accessed 23.08.2021).

Note: Author declares that the paper sent to be published in the Monograph is her own original work, not printed before in other sources in the same form. 